\title{
CONTRIBUTION TO THE KNOWLEDGE OF ORTHOPTERA ON BELASITSA MOUNTAIN, SOUTH-EAST MACEDONIA
}

\author{
Aleksandra Cvetkovska-Gorgievska ${ }^{1 *}$, Dragan P. Chobanov ${ }^{2}$, Dana Prelić ${ }^{1}$, Slavčo Hristovski ${ }^{1}$, \\ Valentina Slavevska-Stamenković ${ }^{1}$, Milica Ristovska ${ }^{1}$ \\ ${ }^{1}$ Institute of Biology, Faculty of Natural Science and Mathematics, P.O. Box 162, Arhimedova 5, \\ 1000 Skopje, Republic of Macedonia \\ ${ }^{2}$ Institute of Biodiversity and Ecosystem Research, Bulgarian Academy of Sciences, \\ 1 Tsar Osvoboditel boulevard, 1000 Sofia, Bulgaria \\ *Corresponding autor; e-mail: acgorgievska@yahoo.com
}

\begin{abstract}
In this paper faunistic data of Orthoptera from Belasitsa Mountain are presented. The research underlying this study was carried out in the period of April-November 2010 at localities along altitudinal gradient at the northern part of the mountain. As a result, 16 species of orthopterans belonging to 6 families, 9 subfamilies and 16 genera were registered.
\end{abstract}

Key words: Orthoptera; Belasitsa Mt.; south-east Macedonia

\section{INTRODUCTION}

First records about Orthopteran fauna of Macedonia were reported by Doflein [1], Berland \& Chopard [2] and Burr et al. [3]. Most of the records, however, concern the present territory of Greece (see Chobanov \& Mihajlova [4]). Later on, Ramme [5-10] and Us [11] added a significant amount of data including new species for the science described by Ramme (see the latter citations). A second period of active studies on the fauna and, partly, taxonomy of the group in Macedonia refers to the work of Karaman (e.g., Karaman [12-22]; for a full list of references see Chobanov \& Mihajlova [4]). Us \& Matvejev [23] made an attempt to synthesize all previous data, though several synonymous taxa were considered with repetitive information or former records for the present territory of Greece were included. Local faunistic contributions were published by Dimovski [24, 25] and single records of Orthoptera are fragmentary available in the literature (see Chobanov \& Mihajlova [4]). The third period of studies started in the 2000s. Local faunistic information has been reported by Chobanov [26] and Micevski et al. [27] and the to-date information on Orthoptera of Macedonia has been critically summarized by Chobanov \& Mihajlova [4]. In addition, three new species have been described from the territory of this country by Chobanov \& Heller [28], Karaman et al. [29] and Chobanov et al. [30], some faunistic records were added by Lemonnier-Darcemont [31], Chobanov et al. [32] and a "Red list of Orthoptera of the Republic of Macedonia" was published by LemonnierDarcemont et al. [33]. Thus, currently the number of recognized species for Macedonia is 171 (with two additional subspecies).

The aim of the present study is to obtain some basic knowledge of the Orthoptera fauna of the northern part of Belasitsa Mountain. Although the Orthopteran fauna of Belasitsa was thoroughly studied on the territory of Bulgaria (e.g., $[34,35]$ ), presently there are no records from the Macedonian part of this area. In addition we present the records of Orthoptera from Belasitsa Mountain collected in the period April-November 2010.

\section{AREA OF RESEARCH}

Belasitsa Mountain is situated in the southeastern part of Macedonia, bounded between Bulgaria and Greece (Figure 1a). It is among the smallest by 
area mountains in Macedonia. From the neighbouring mountains Belasitsa is separated with the river valleys of Vardar in the west, Struma in the east, Strumicka in the north and Dojranska and Serska in the south. According to the altitude, it belongs to the group of high mountains (over $2000 \mathrm{~m}$ ) [36].

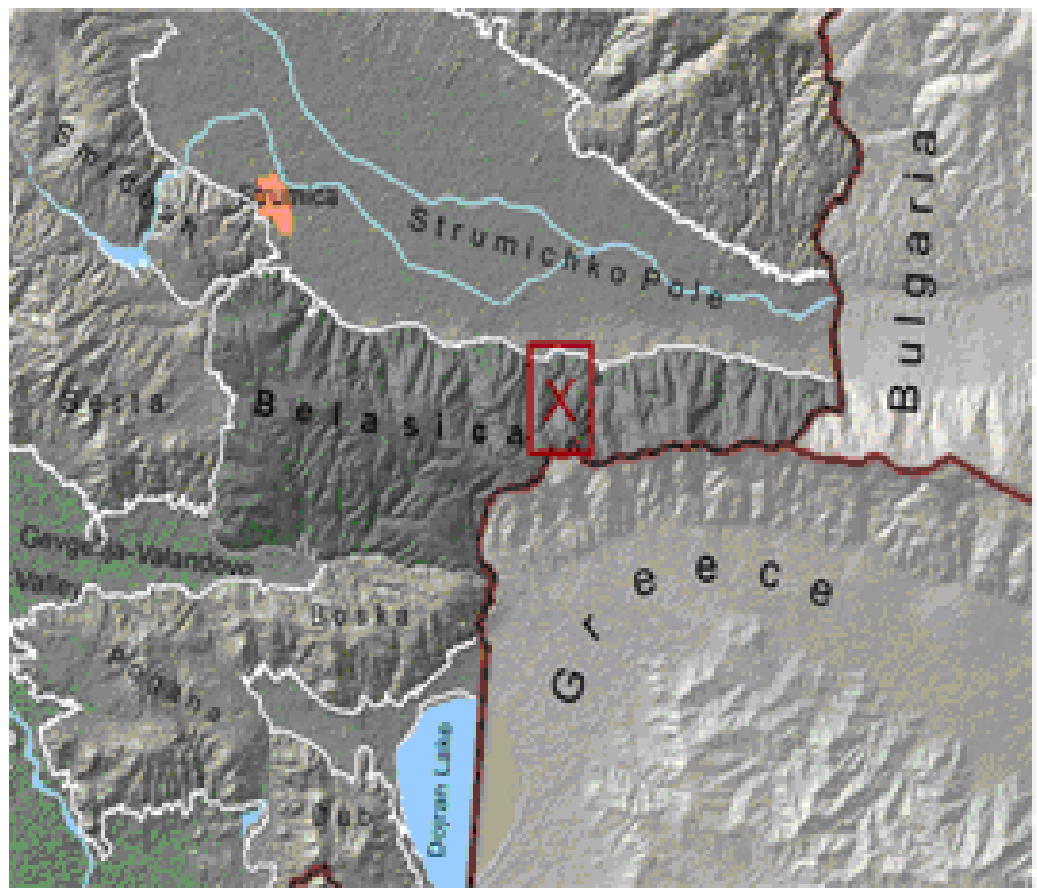

(a)

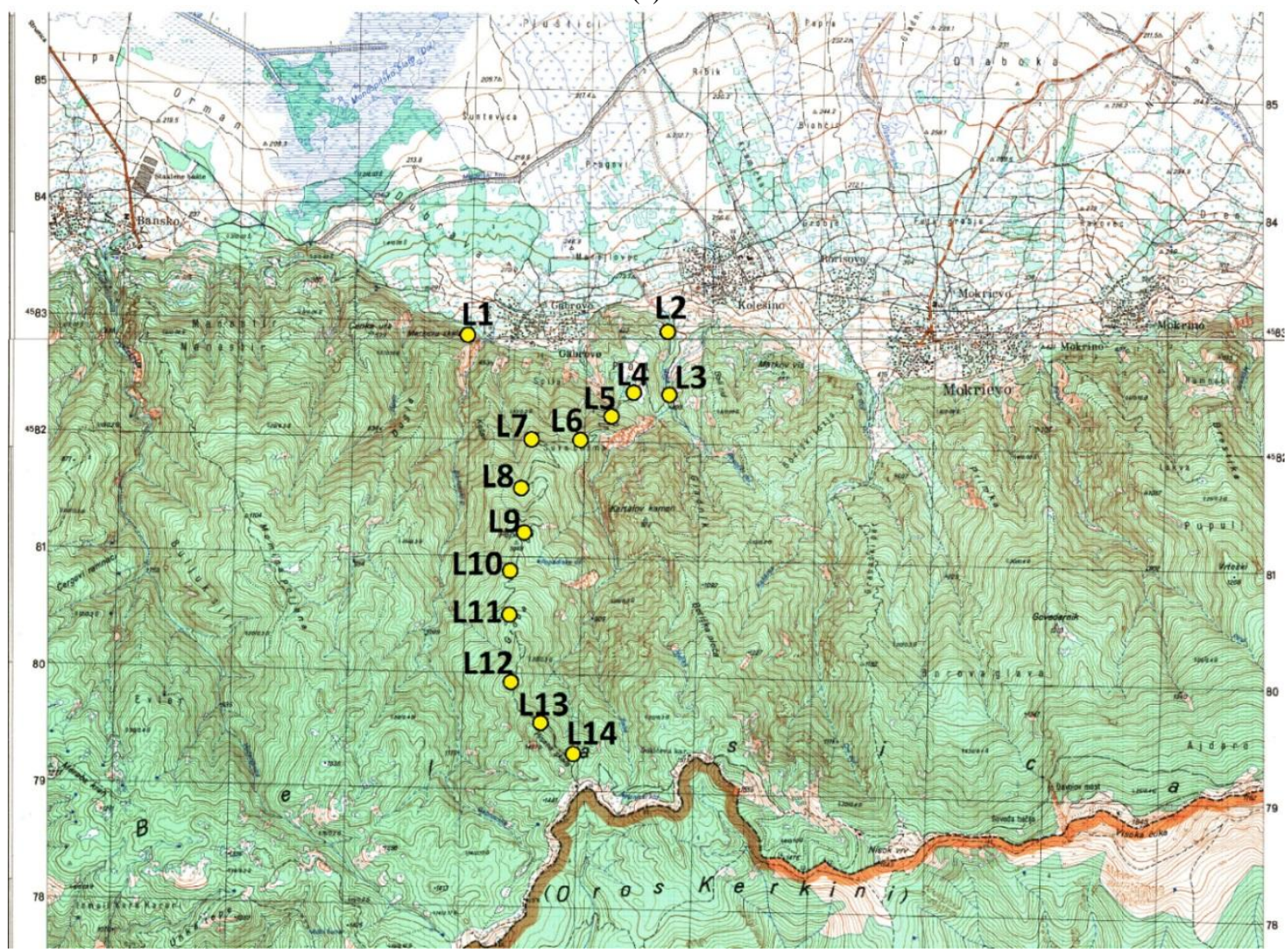

(b)

Figure 1a and b. Topographic map of the investigated area and localities on Belasitsa Mountain 
The highest peak is Radomir (Kalabak) - $2029 \mathrm{~m}$ at the border between Bulgaria and Greece. The highest peak on the territory of Macedonia is Tumba $(1881 \mathrm{~m})$, located at the border with the neighbouring countries Greece and Bulgaria. In the central part of the mountain (within Macedonia) the peak Visoka Chuka (1845 m) dominates, and in the eastern part - the peak Samer $(1877 \mathrm{~m})$.

From the structural-geological point of view, Belasitsa is a typical linear horst. It was formed as a mountain block during Pliocene between two parallel seedlings bounded in the north and in the south, rising as a horst between two sinking anticlinoria.

The mountain is built mainly out of metamorphic rocks - amphibolites, different types of minerals, granite, gneiss, etc. The oldest are gneissmetamorphic rocks from the crystalline slates group of archaic age.

The low parts of the mountain are characterized by cimet-forest soils, and in the higher parts the brown-forest and mountain-meadow soils are most common. The belt between 600 and $1800 \mathrm{~m}$ is characterized by brown-forest soils.

The climate in the low-mountain belt $(300$ $1000 \mathrm{~m}$ ) is mountain continental with Mediterranean influence, while the mountain belt over $1000 \mathrm{~m}$ alt. is influenced by the cold continental climate [37].

\section{MATERIAL AND METHODS}

The research was carried monthly, during the period April - November 2010, on Belasitsa Mountain. Fourteen localities (L1-L14) at different altitudes (240 m - $1450 \mathrm{~m}$ above s.1.) along an altitudinal gradient (Figure $1 \mathrm{~b}$ and Figures 2a-n) were selected. The vegetation cover is represented by several climazonal forests: first five localities (L1L5) are covered by the association QuercoCarpinetum orientalis macedonicum Rudski apud $\mathrm{Ht}$; L6-L9 are dominated by the association OrnoQuercetum petraeae Em; L10 is disposed within the association Festuco heterophyllae-Fagetum; L10L13 and L14 are allocated within the association Calamintho grandiflorae-Fagetum (L14 representing clear-cut area).

The samples were collected using pitfall traps, representing a plastic cup with a volume of 0,5 liter. In total 140 traps were placed in 14 different localities referring to different altitudes on Belasitsa Mountain. At each locality 10 pitfall traps were placed along a transect line following the isohypse. The traps were $10 \mathrm{~m}$ apart in order to avoid possible interference between them. The upper edge of the trap was placed parallel to the soil surface. Formaldehyde-vinegar solution $(1: 7 ; 200 \mathrm{ml})$ was used as a preservative.

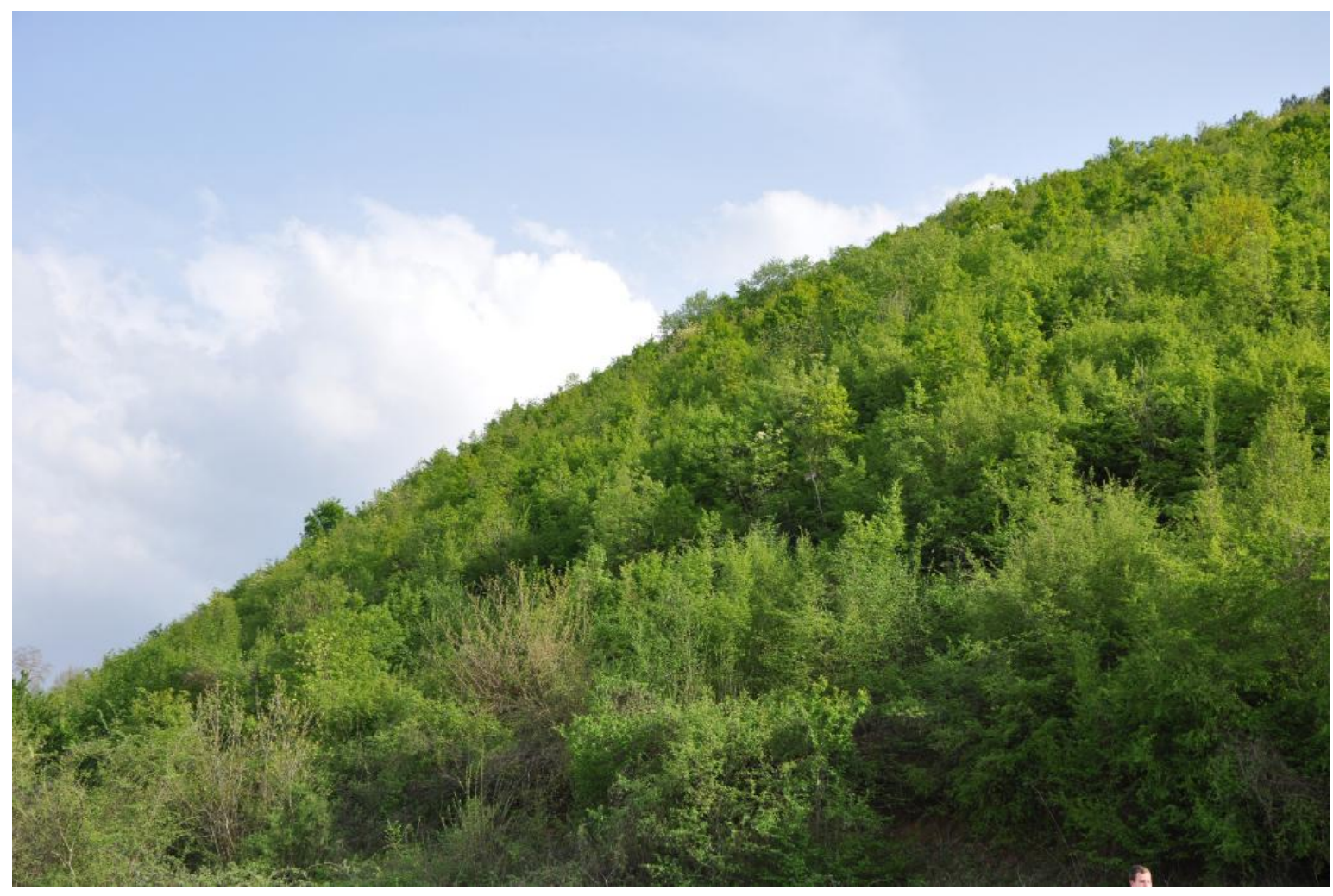

2a. L1 


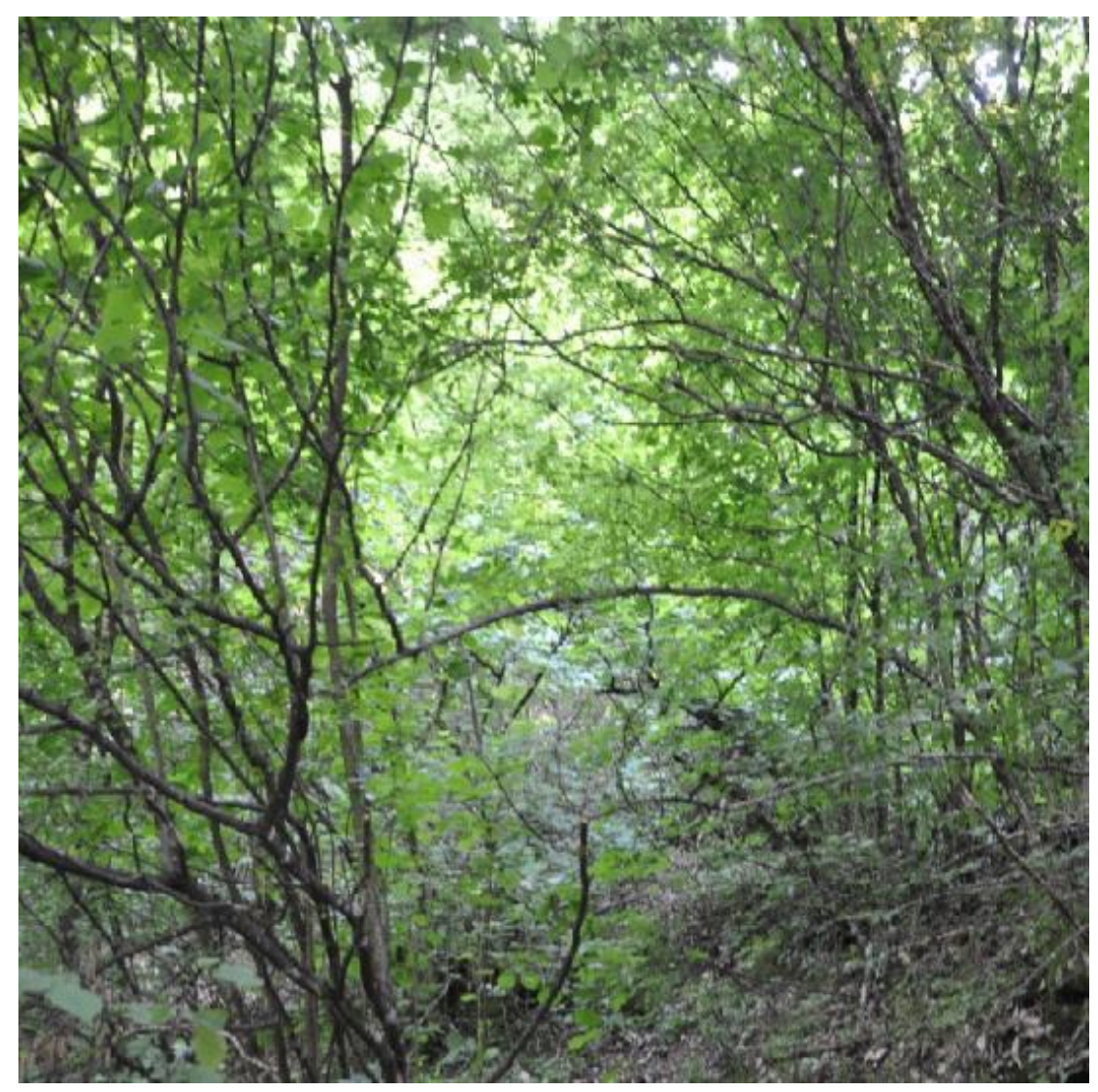

2b. L2

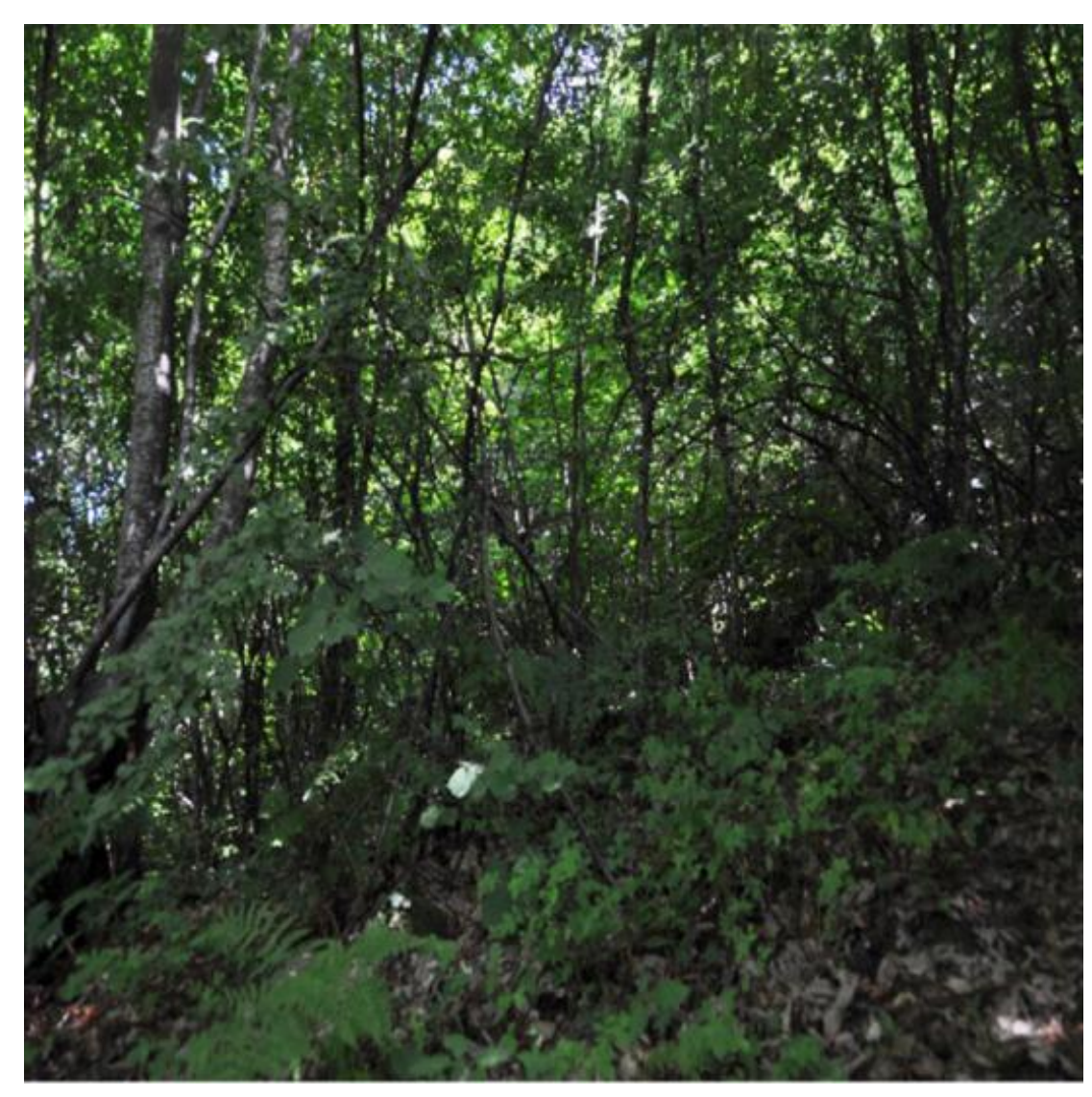

2c. L3 


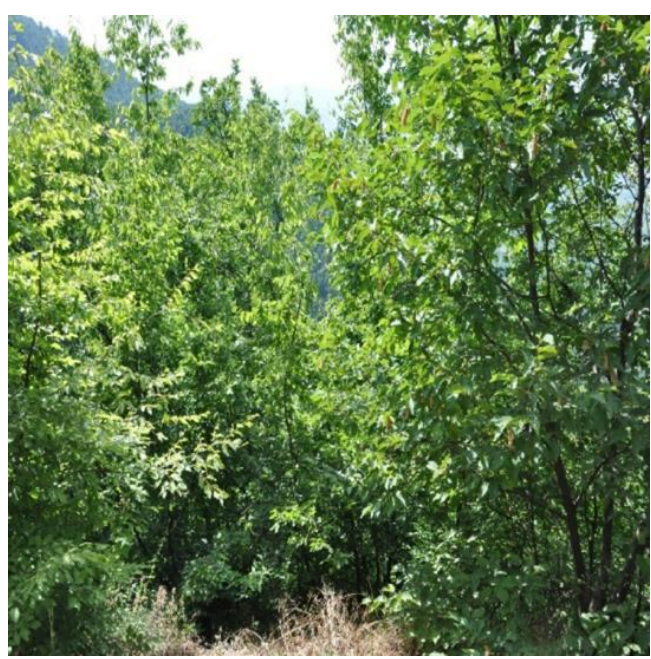

2d. L4

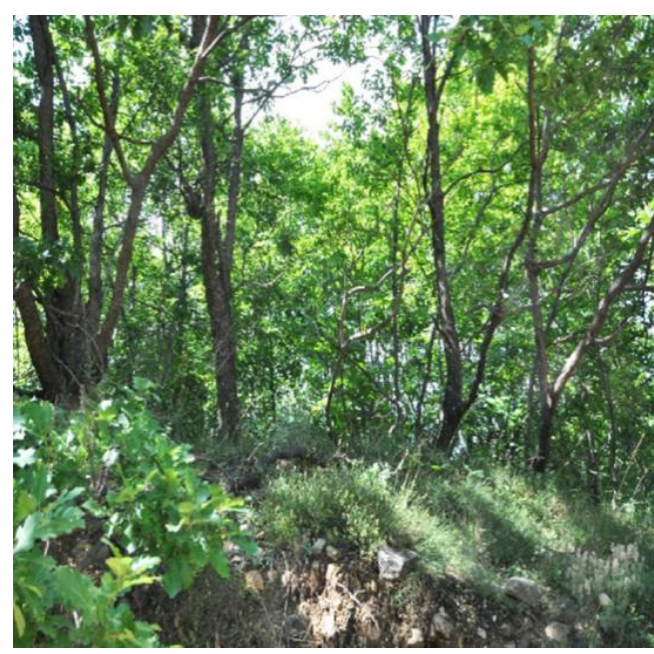

2e. L5

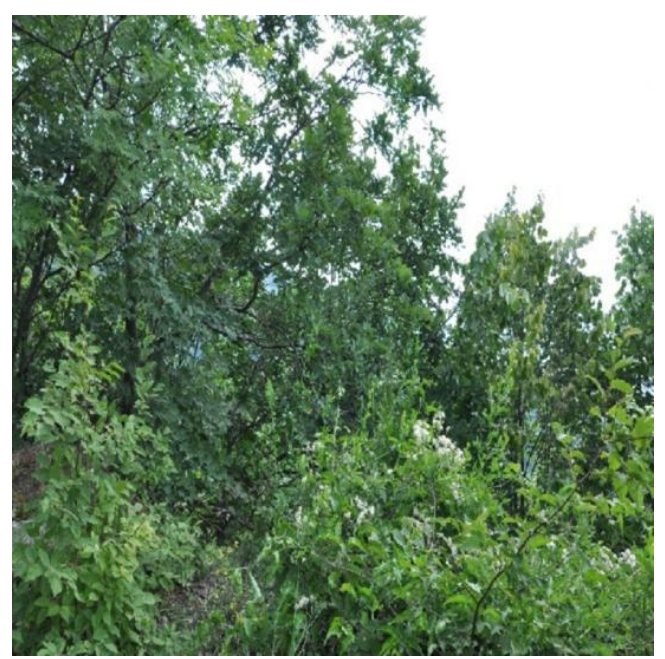

2f. L6

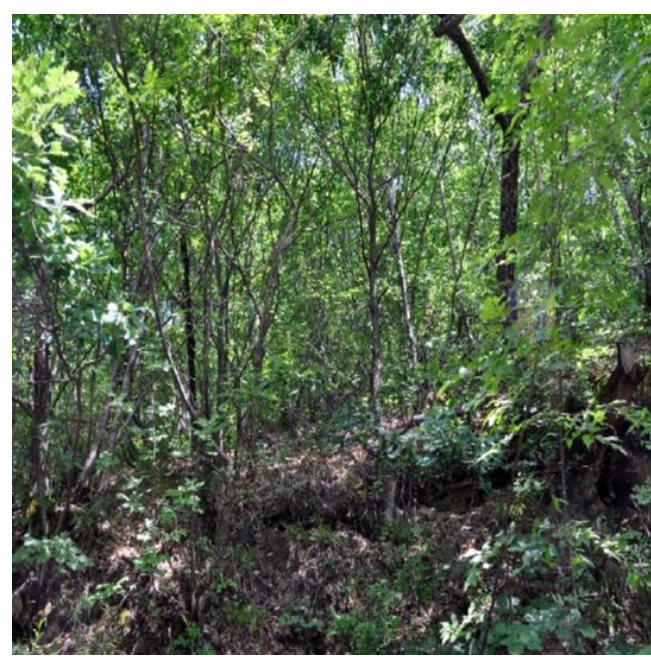

2g. L7

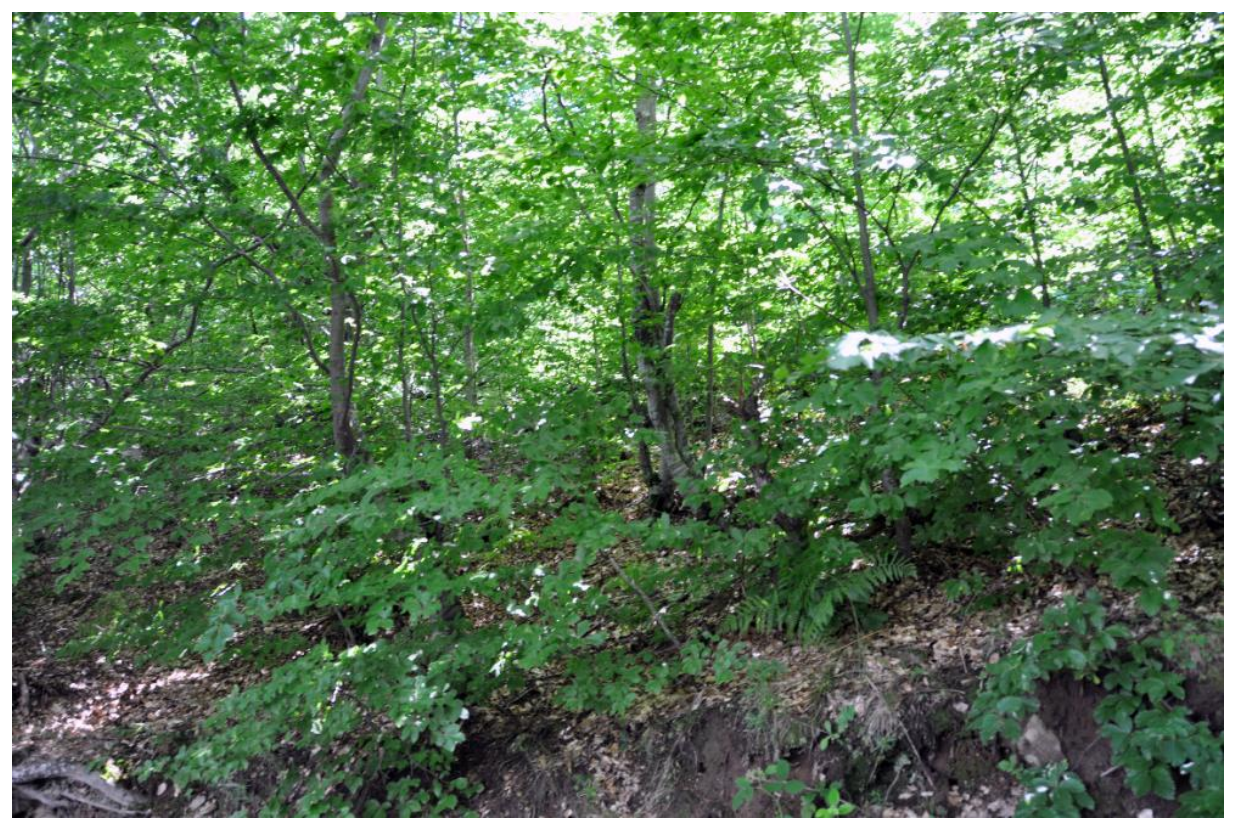

2h. L8 


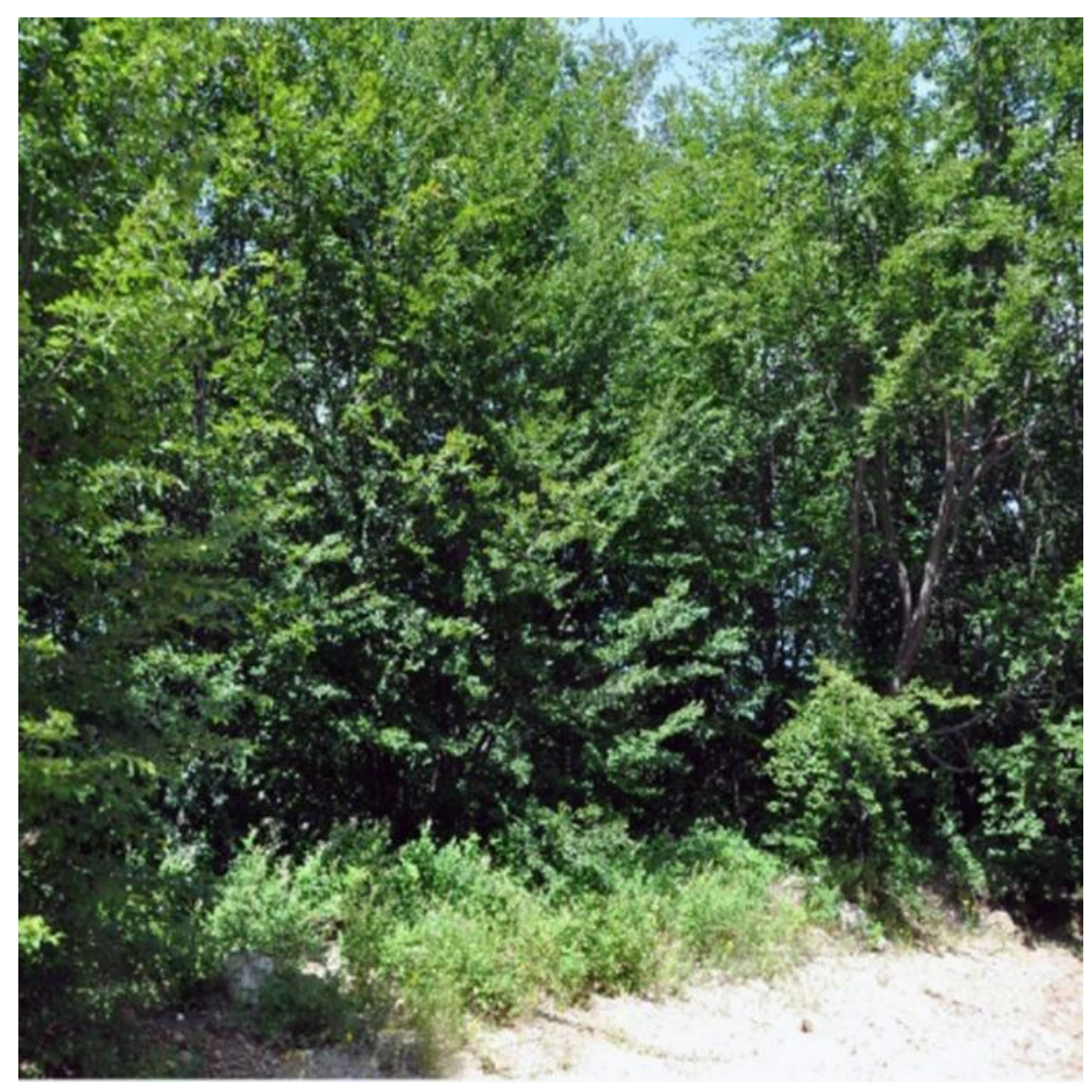

2i. L9

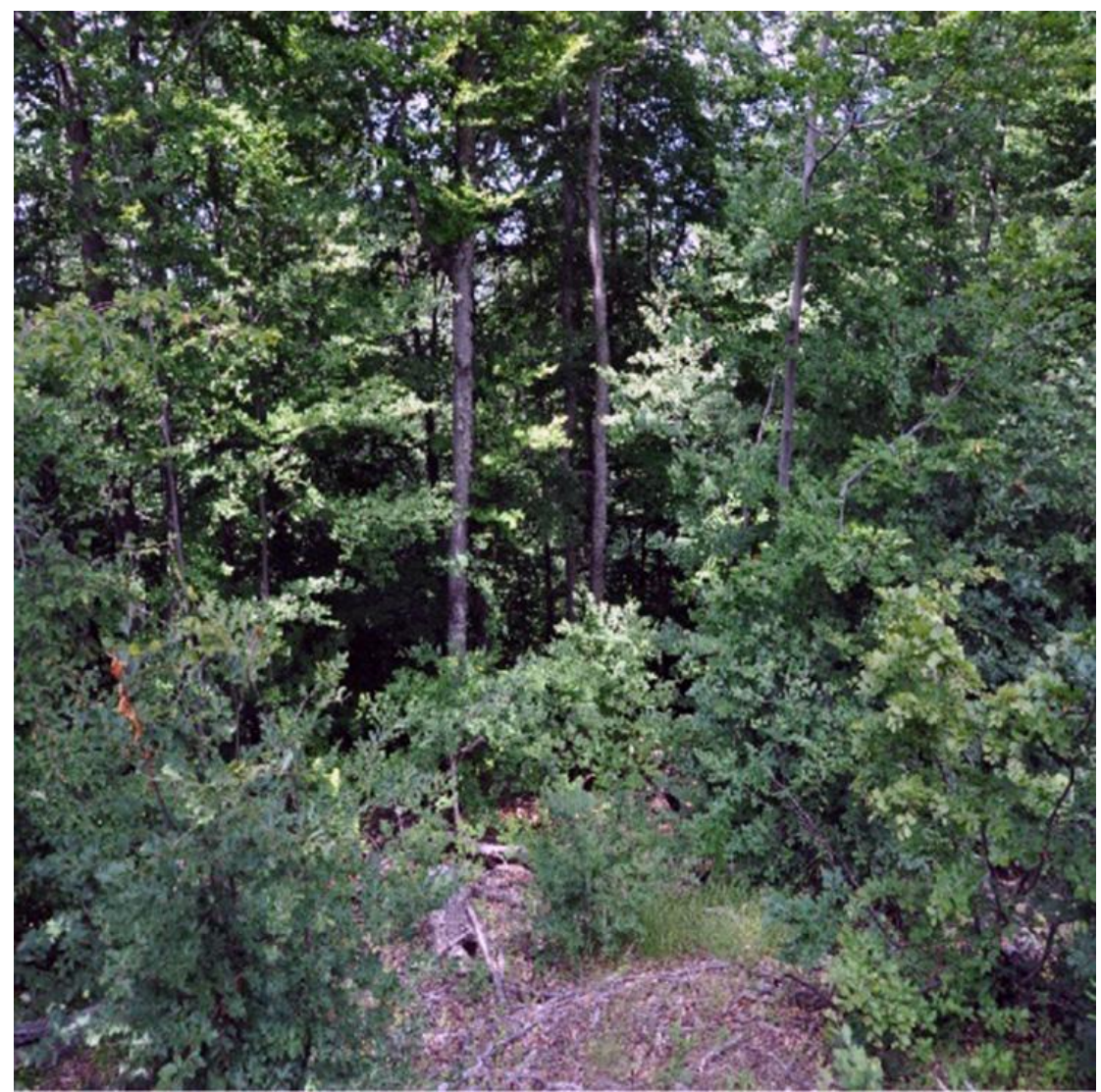

2j. L10

Contributions, Sec. Nat. Math. Biotech. Sci., MASA, 36 (2), 121-133 (2015) 


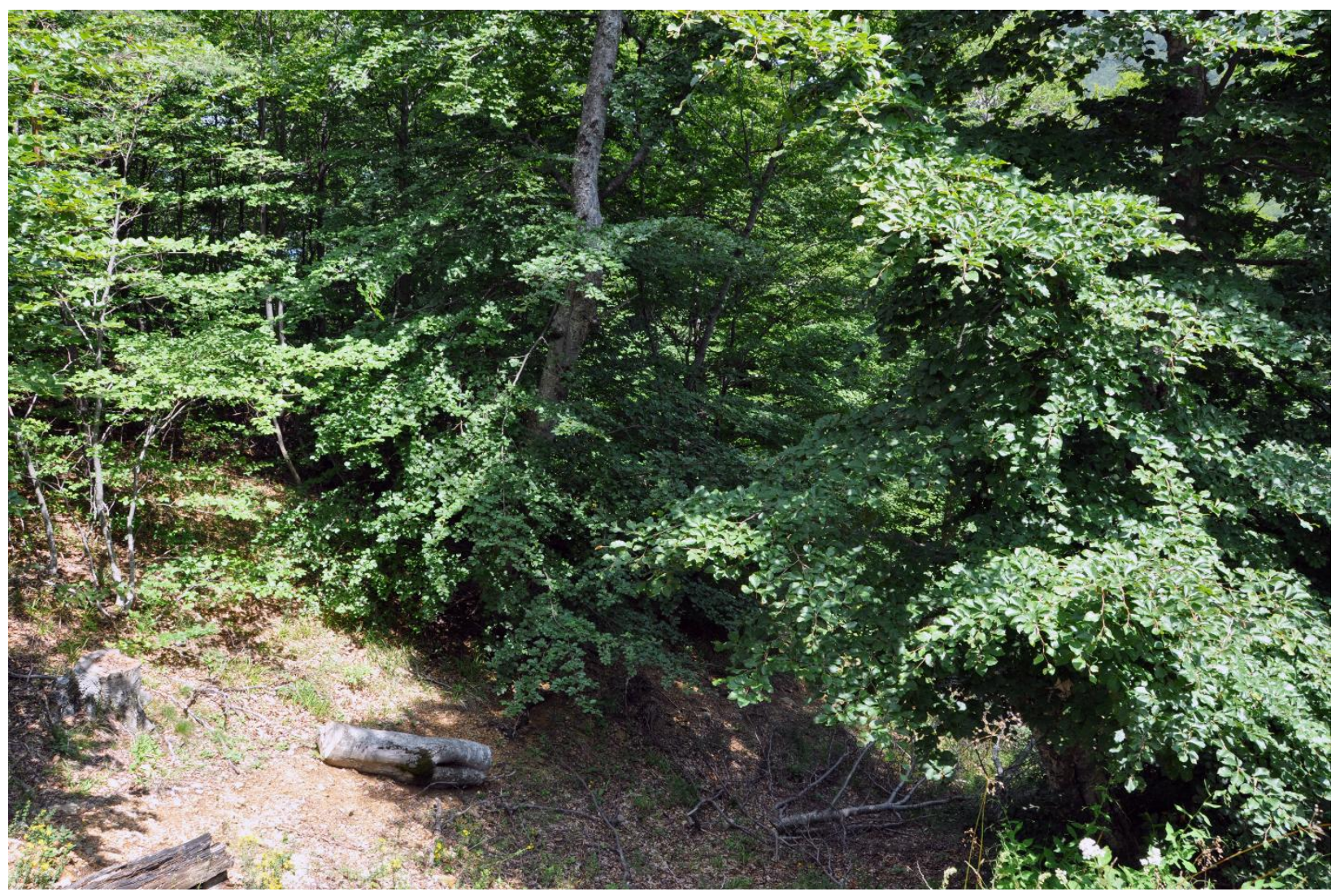

2k. L11

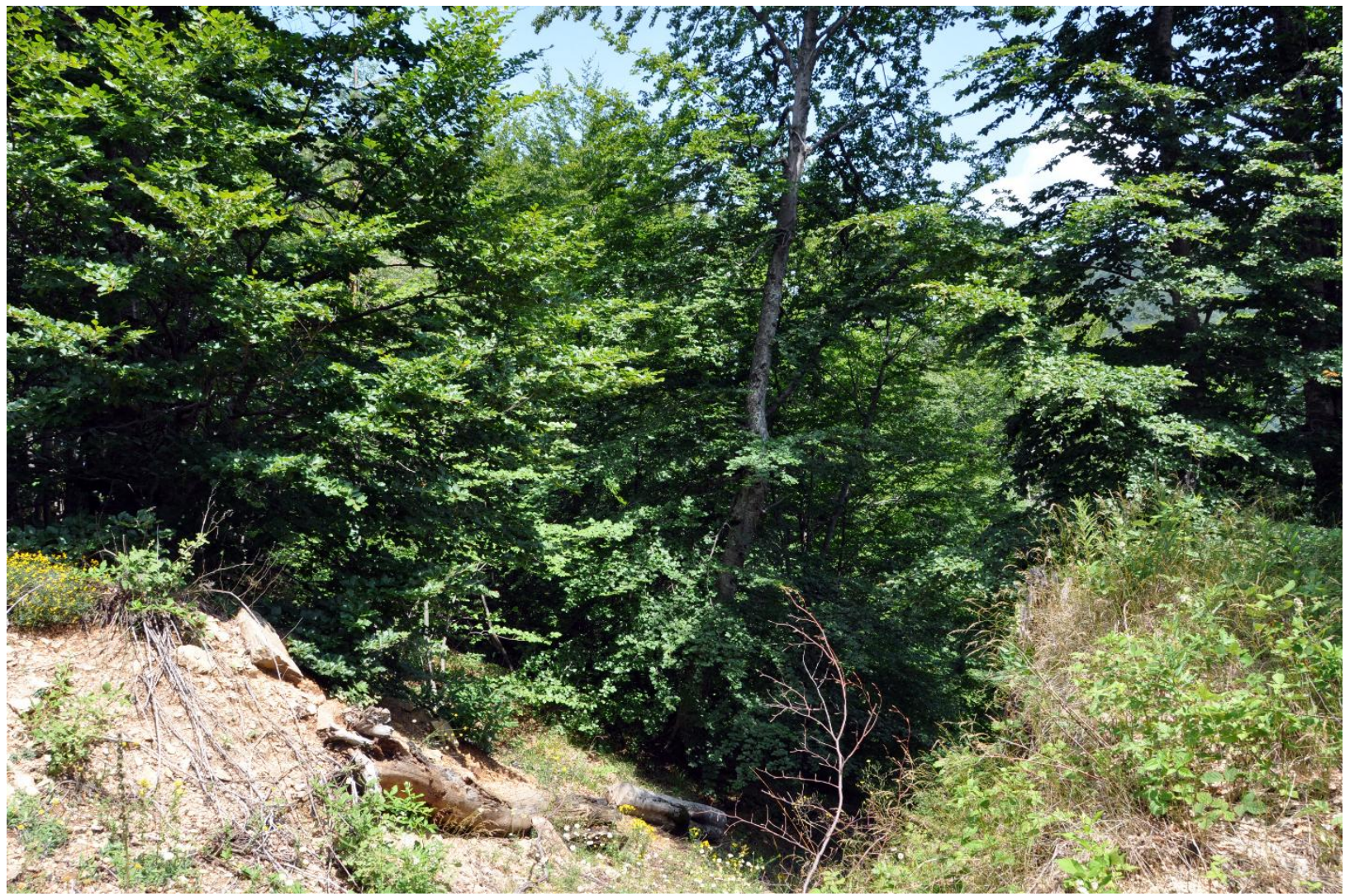

2l. L12 


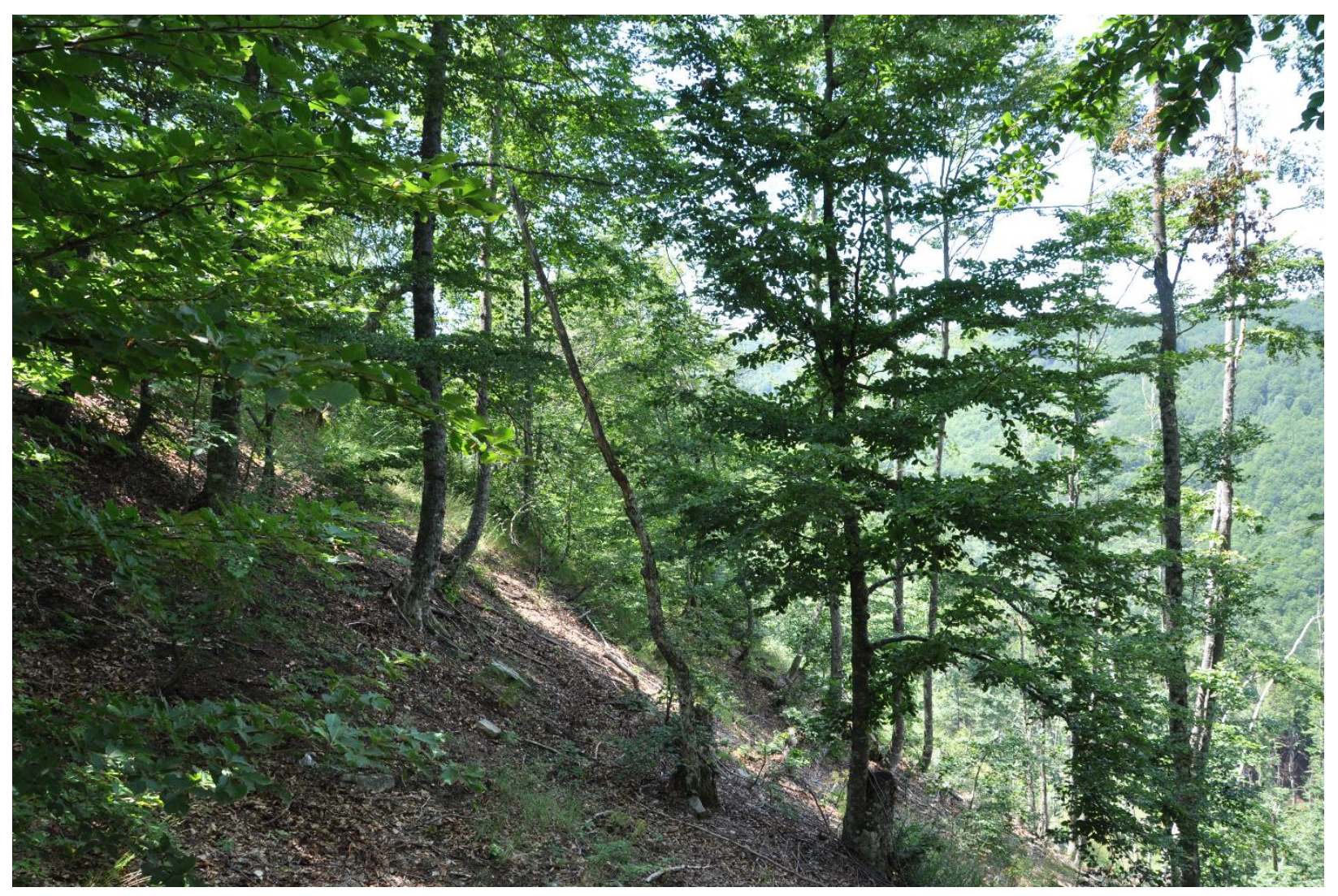

2m. L13

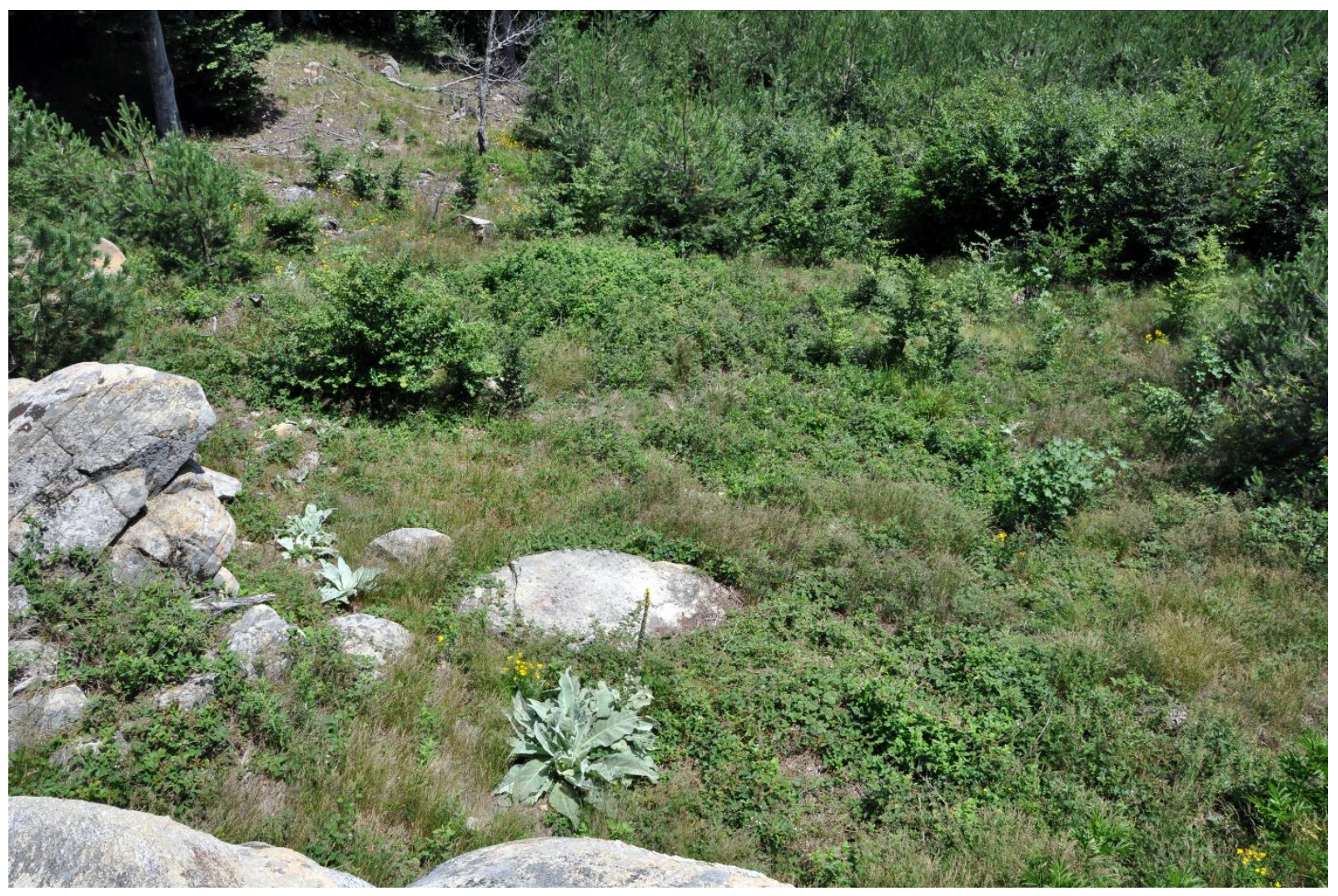

2n. L14

Figure 2a-n. Localities on Belasitsa Mountain 


\section{ACRONYMS USED IN THE TEXT}

L1 - 250 m; ass. Querco-Carpinetum orientalis macedonicum Rudski apud $\mathrm{Ht}$; near the locality Markova Skala.

L2 - $327 \mathrm{~m}$; ass. Querco-Carpinetum orientalis macedonicum Rudski apud Ht; under the viewing point which is near the Koleshinski Waterfall.

L3 - 415 m; ass. Querco-Carpinetum orientalis macedonicum Rudski apud $\mathrm{Ht}$; near Koleshinski Waterfall.

L4 - $500 \mathrm{~m}$; ass. Querco-Carpinetum orientalis macedonicum Rudski apud Ht; near the locality "Pod".

L5 - $587 \mathrm{~m}$; ass. Querco-Carpinetum orientalis macedonicum Rudski apud $\mathrm{Ht}$; between the localities "Pod" and "Suva Cheshma".

L6 - 693 m; ass. Orno-Quercetum petraeae Em; near the locality "Suva Cheshma".

L7 - 767 m; ass. Orno-Quercetum petraeae Em; near the locality "Popadija".

L8 - 847 m; ass. Orno-Quercetum petraeae Em; near the locality "Popadija".

L9 - 1038 m; ass. Orno-Quercetum petraeae Em; near the locality "Popadija".

L10 - $1100 \mathrm{~m}$; ass. Festuco heterophyllaeFagetum; after the locality "Popadija".

L11 - $1200 \mathrm{~m}$; ass. Calamintho grandifloraeFagetum; after the locality "Popadija".

L12 - $1300 \mathrm{~m}$; ass. Calamintho grandifloraeFagetum; after the locality "Groba".

L13 - $1385 \mathrm{~m}$; ass. Calamintho grandifloraeFagetum; near the locality "Pisana Skala".

L14 - $1442 \mathrm{~m}$; ass. Calamintho grandifloraeFagetum; near the locality "Pisana Skala".
(1) - April 2010
(2) - May 2010
(3) - June 2010
(4) - July 2010
(5) - August 2010
(6) - September 2010
(7) - October 2010
(8) - November 2010
+ - female $\hat{o}$ - male

\section{RESULTS AND DISCUSSION}

As a result of the present study, 16 species of Orthopterans belonging to 6 families, 9 subfamilies and 16 genera were sampled. This number represents $22 \%$ of the species found in the Bulgarian part of the mountain and $9 \%$ of the species currently recorded from Macedonia. Therefore, our findings represent only a minor part of the taxa that are expected to occur in the Macedonian part of Belasitsa Mountain. The low number of taxa may be explained with a combination of factors: (1) the sampling has been conducted almost exclusively in forested habitats that are inhabited by a low number of orthopterans; (2) using a very specific collecting technique (soil traps) additionally may restrict the collecting success, avoiding the sampling of highly mobile species; (3) collecting has been performed on a single altitudinal line at the northern slope of the mountain. Thus, the present study is only an initial step for further complete investigations of the Orthopteran fauna of Belasitsa. Combining different collecting approaches in all plant associations of the mountain (including its southern slope with a well expressed Mediterranean climate influence) the number of species of Orthoptera is expected to reach at least 80 .

\section{Species list:}

\section{Suborder Ensifera}

Family Phaneropteridae

Subfamily Phaneropterinae

Genus Barbitistes Charpentier, 1825

1. Barbitistes ocskayi Charpentier, 1850: L4 (2) - 1 nymph; L5 (3) - 1 adult + .

Distribution: Balkan subendemic species known from south-west Romania, west Bulgaria, Serbia, Montenegro, north Greece, Albania, Bosnia and Herzegovina, Croatia, Slovenia and north-east Italy.

Distribution in Macedonia: Presently known only from the Vardar valley to the south of Skopje, but according to our own unpublished data it is much widely distributed in the lowland and hilly belt of the country.

Family Tettigoniidae

Subfamily Meconematinae

Genus Meconema Serville, 1831

2. Meconema thalassinum (De Geer, 1773): L6 (4) - 1 adult $\widehat{o}$.

Distribution: Widespread across Europe.

Distribution in Macedonia: Common but scarcely recorded from the country. The species occurs in deciduous forests and shrubs from the lowland up to $1300 \mathrm{~m}$ alt. (unpublished data).

Subfamily Tettigoniinae

Genus Metrioptera Wesmael, 1838

3. Metrioptera tsirojanni Harz \& Pfau, 1983: L14 (5) - 1 adult + ; L14 (7) -1 adult,+ 1 nymph.

Distribution: Regional endemic for the central part of the Balkan Peninsula (south-east Serbia, east Macedonia, north Greece and south-west Bulgaria). 
Distribution in Macedonia: Inhabits the hilly and mountainous areas of the eastern and central parts of Macedonia.

Genus Bucephaloptera Ebner, 1924

4. Bucephaloptera bucephala (Brunner von Wattenwyl, 1882): L5 (3) - 1 nymph.

Distribution: East-mediterranean species, occurring in the eastern part of the Balkan Peninsula and western Anatolia.

Distribution in Macedonia: Recorded from the valleys in almost whole Macedonia up to about 800 m alt.

Genus Pholidoptera Wesmael, 1838

5. Pholidoptera macedonica Ramme, 1928: L7 (5) - 1 adult ô.

Distribution: Balkan endemic species distributed in Macedonia, Greece and south-west Bulgaria.

Distribution in Macedonia: Found in most of the mountainous areas of this country except the Osogovo-Ograzhden mountain group (own unpublished data).

\section{Genus Eupholidoptera Maran, 1953}

6. Eupholidoptera schmidti (Fieber, 1861): L4 (3) - 1 nymph; L5 (4) -1 adult ô; L7 (5) - 1 adult + ; L8 (4) - 1 nymph.

Distribution: Balkan subendemic species westwards reaching northeastern Italy.

Distribution in Macedonia: According to published (compare Chobanov \& Mihajlova 2010) and own unpublished data E. schmidii (formerly also recorded as E. chabrieri (Charpentier, 1825)) occurs in the lowland and hilly belt of the whole country.

\section{Genus Rhacocleis Fieber, 1853}

7. Rhacocleis germanica (Herrich-Schaffer, 1840): L5 (6) - 2 adults $\odot$; L7 (7) - 1 adult $~+$.

Distribution: Widespread in southern Europe between south France and Moldavia, northwards reaching Slovakia.

Distribution in Macedonia: Common in the lowlands of the whole country, mostly keeping to xerophyte grass-shrub associations up to $1300 \mathrm{~m}$ alt.

Superfamily Rhaphidophoroidea

Family Rhaphidophoridae

Subfamily Troglophilinae

Genus Troglophilus Krauss, 1879

8. Troglophilus brevicauda Chopard, 1934: L6 (6) - 1 nymph; L7 (3) - 1 adult + , 3 nymphs; L7
(4) - 1 adult 3 ; L7 (5) - 1 nymph; L7 (6) - 1 adult o); L8 (6) -1 adult 9 , 2 nymphs; L12 (2) -2 adults +, 1 nymph; L12 (3) - 1 adult + ; L12 (4) - 3 nymphs; L12 (6) - 1 adult ${ }^{\widehat{T}}, 3$ nymphs; L12 (7) - 1 adult $\widehat{\jmath}, 2$ nymphs.

Distribution: Regional endemic species for the Balkan Peninsula, known from west Serbia, east Bosnia and Herzegovina and north Montenegro, as well as in a remote range from south-east Macedonia (Plachkovitsa, Belasitsa Mts) to south Bulgaria (Karaman et al. [29]).

Distribution in Macedonia: Presently known from Plachkovitsa and Belasitsa mountains (see above). Inhabits humid leaf litter, soil crevices and caves.

Superfamily Grylloidea

Family Gryllidae

Subfamily Gryllomorhinae

Genus Gryllomorpha Fieber, 1853

9. Gryllomorpha (Gryllomorpha) dalmatina (Ocskay, 1832): L1 (3) - 4 nymphs; L1 (7) - 1 adult $\hat{\jmath}$; L2 (4) -1 adult $\hat{\jmath}, 5$ nymphs; L2 (6) -1 adult +; L2 (7) - 2 nymphs; L2 (8) -1 adult $\hat{0}, 1$ adult + , 1 nymph; L3 (4) - 2 nymphs; L3 (7) - 1 adult + , 2 nymphs; L4 (4) -3 nymphs; L4 (6) - 1 adult + , 1 adult ${ }^{1}$; L4 (7) -2 nymphs; L4 (8) - 1 nymph; L5 (3) - 12 nymphs; L5 (4) - 1 adult + , 6 nymphs; L5 (6) -1 adult 0 , 2 adult,+ 3 nymphs; L5 (7) - 1 adult $\hat{\rho}, 2$ adult,+ 17 nymphs; L5 (8) -5 nymphs; L6 (3) - 1 nymphs; L6 (7) - 4 nymphs; L6 (8) - 2 nymphs; L7 (4) - 2 nymphs; L7 (7) -6 nymphs; L7 (8) - 2 nymphs; L8 (8) - 1 nymph.

Distribution: Holomediterranean species, eastwards reaching the Caucasus region.

Distribution in Macedonia: Presently recorded from the city of Skopje (Chobanov \& Mihajlova, 2010). The species seems, however, widely distributed in the lowland areas of the country but its nocturnal activity and hidden life makes it difficult to observe and collect by the standard insect collecting techniques.

Subfamily Oecanthinae

Genus Oecanthus Serville, 1831

10. Oecanthus pellucens pellucens (Scopoli, 1763): L4 (4) - 1 nymph.

Distribution: Widely distributed in the Mediterranean and Central Europe. Its range in North Africa and Central Asia needs clarification due to the possible misidentification of Oe. dulcisonans Gorochov, 1993 and Oe. turanicus Uravov, 1912. 
Distribution in Macedonia: Widely distributed all over Macedonia up to $1450 \mathrm{~m}$ in the mountains (Micevski et al. 2003).

\section{Suborder Caelifera}

Superfamily Acridoidea

Family Acrididae

Subfamily Melanoplinae

Genus Podisma Berthold, 1827

11. Podisma pedestris pedestris (Linnaeus, 1758): L14 (4) - 3 adults + +; L14 (5) - 1 adult $\widehat{\jmath}, 2$ adults + ; L14 (6) -2 adults $\widehat{\jmath}, 2$ adults +.

Distribution: Euro-Siberian species and subspecies. In the northern areas of its distribution $P$. pedestris occurs mostly in the lowlands, while southwards inhabits mostly mountainous area and rarely can be found in lowland forests.

Distribution in Macedonia: Common in all high mountains above $1500 \mathrm{~m}$ alt. Fragmentary occurs in humid lowland habitats (found near Skopje, in the municipality of Dračevo; Chobanov \& Mihajlova 2010).

Subfamily Catantopinae

Genus Pezottetix Burmeister, 1840

12. Pezotettix giornae (Rossi, 1794): L5 (7) -1 adult $\hat{\rho}, 3$ adults + .

Distribution: Holomediterranean species, widespread in southern Europe, Northeast Africa, Asia Minor, reaching eastwards to the northern Caucasus.

Distribution in Macedonia: Common all over the country in open habitats and sparse groves in the lowlands up to $1100 \mathrm{~m}$ (by exception to 1600 m; Micevski et al. 2003).

Subfamily Oedipodinae

Genus Aiolopus Fieber, 1853

13. Ailopus strepens (Latreille, 1804): L5 (7) -1 adult + .

Distribution: Widely distributed around Mediterranean eastward reaching North Iran.

Distribution in Macedonia: Common in the whole country up to $1600 \mathrm{~m}$ in the mountains.

Subfamily Gomphocerinae

Genus Euthystira Fieber, 1853

14. Euthystira brachyptera (Ocskay, 1826): L14 (6) - 1 adult 9 .

Distribution: Euro-Siberian species, settles moderately wet to very wet meadows and uplands between 1200 to $2000 \mathrm{~m}$ (Micevski et al. 2003).
Genus Stauroderus Bolivar, 1898

15. Stauroderus scalaris scalaris (Fischer de Waldheim, 1846): L14 (4) - 1 adult + , 1 nymph; L14 (5) - 2 adults + .

Distribution: Palaearctic species.

Distribution in Macedonia: Widely distributed in open habitats in the middle mountain belt, usually between 1000 and $2000 \mathrm{~m}$ alt.

Genus Chorthipus Fieber, 1852

16. Chorthippus bornhalmi Harz, 1971: L5 (3) -1 adult $~+$; L7 (7) - 1 adult $\odot ;$ L14 (3) - 1 adult $~+$.

Distribution: The species is currently recorded from Italy, the western and southern Balkans and Asia Minor.

Distribution in Macedonia: One of the most widely distributed species in Macedonia occurring in diverse (mostly xeromorphic) habitats from the lowlands to the highest mountain summits.

\section{CONCLUSION}

This paper represents taxa that are expected to occur in the Macedonian part of Belasitsa Mountain and provides additional information on the occurrence of Orthoptera fauna. However, further studies are necessarily to improve our knowledge of Orthopteran fauna on Belasitsa Mountain as part of a higher biodiversity region.

\section{REFERENCES}

[1] F. Doflein, Mazedonien, Ergeb. Biol. Natural. Gef. deutsch. Heeres, Jena, (1921).

[2] L. Berland, L. Chopard, Traveaux scientifiques de l'armée d'Orient (1916-1918) Orthoptères, Bulletin du Muséum nationale d'histoire naturelle, Paris, 28 (1922), pp. 166-170, 230-235.

[3] M. Burr, B. Cambell, B. Uvarov, A contribution to our knowledge of the Orthoptera of Macedonia, Transac. Entom. Soc., London (1923).

[4] D. P. Chobanov, B. Mihajlova, Orthoptera and Mantodea in the collection of the Macedonian Museum of Natural History (Skopje) with annotated check-list of the groups in Macedonia, Articulata 25, (2010), pp. 73-107.

[5] W. Ramme, Neue und wenig bekannte europäische und asiatische Orthopteren (Acrid., Tettigon.), Deutsche entomologische Zeitschrift, (1926), pp. 273-289.

[6] W. Ramme, Neue balkanische Decticini (Orth. Tettigon.), Deutsche entomologische Zeitschrift, (1928), pp. 302-304.

[7] W. Ramme, Beiträge zur Kenntnis der palaearktischen Orthopterenfauna (Tettig., et 
Acrid.), Mitteilungen aus dem Zoolog. Museum in Berlin, 17 (1931), pp.165-200.

[8] W. Ramme, Beiträge zur Kenntnis der palaearktischen Orthopterenfauna (Tettig., et Acrid.) II, Mitteilungen aus dem Zoologischen Museum in Berlin, 18 (1933), pp. 416-434.

[9] W. Ramme, Beiträge zur Kenntnis der palaearktischen Orthopterenfauna (Tettig., et Acrid.) III, Mitteilungen aus dem Zoolog. Museum in Berlin, 24 (1939), pp. 41-150.

[10] W. Ramme, Zur Systematik Faunistik und Biologie der Orthopteren von Südost-Europa und Vorderiesen, Mitteilungen aus dem Zoologischen Museum in Berlin, 27 (1951), pp. 1-432.

[11] P. Us, Doprinos poznavanju ortopterske faune $\mathrm{u}$ Jugoslaviji, Prirodoslovne razprave (Ljubljana), 3 (1938), pp. 239-252 (In Serbo-Croatian).

[12] M. S. Karaman, Prilog poznavanju pravokrilaca okolice Skopja. - Zaštita bilja, 4 Beograd, (1958a), pp. 111-114

[13] M. Karaman Neue Orthopteren-Arten aus Jugoslawien, unsbesonders aus Mazedonien, Biološki Glasnik, 11 Zagreb, (1958b), pp.35-44.

[14] M. Karaman, Sur une sauterelle de Macedoine, Melanoplus frigidus dimovskii n. ssp. (Orthoptera. Cantanthopidae), Bull. Soc. Entomologique de Mulhouse, Novembre-Decembre, Mulhouse, (1959).

[15] M. S. Karaman, Beitrag zur Kenntnis der Gattung Pholidoptera Wesm. (Orth. Tettigoniidae) in Mazedonien, Fragmenta Balcanica (Skopje) 3 (1960a), pp. 21-30.

[16] M. S. Karaman, Metaplastes ornata Rme, une nouvelle sauterelle pour la faune Yougoslave, Bull. Soc. Entomologique de Mulhouse (1960b), pp. 9193.

[17] M. S. Karaman, Tetrigidae Mazedoniens, Zaãtita bilja (Belgrade) 57/58 (1960c), pp. 143-161, (In Serbo-Croatian, German summary).

[18] M. S. Karaman, Beitrag zur Kenntnis der Orthopteren Jugoslawiens, Fragmenta Balcanica (Skopje) 4 (5) (1961a), pp. 37-48.

[19] M. S. Karaman, Beitrag zur Kenntnis der Orthopteren Mazedoniens, Mitteilungen der Münchener entomologischen Gesellschaft $\mathbf{5 1}$ (1961b), pp. 111-117.

[20] M. S. Karaman, Poecilimon chopardi Rme (Orthopt. Phaneropteridae) de Macedonie, Bull. Soc. Entomologique de Mulhouse, (1962), pp. 69-70.

[21] M. S. Karaman, Un nouveau grillon myrmécophile Myrmecophila zorae n. sp. de Macé-doine, Bull. Soc. Entomologique de Mulhouse, (1963), pp. 5-6.

[22] M. S. Karaman, Etude taxonomique, zoogéographique et ékologique des Orthopteroides de la plaine de Skoplje, Zajednica Naü̈nih Ustanova Sap Kosova Knjiga 35, Priãtina, (1975), 156 p. (In Serbo-Croatian, French and Albanian summaries).
[23] P. Us, S. Matvejev, Orthopteroidea, Catalogus Faunae Jugoslaviae, III/6, Academia Scientarum et Artium Slovenica, Ljubljana, (1967), 47 p. (In Serbo-Croatian).

[24] A. Dimovski, Die Biogeographische und Ökologische Charakteristik des Kessels von Skopje, Annuaire de la Faculte des Sciences de l'Universite de Skopje 20, 1967, (1968), pp. 1-70, (In Macedonian, German summary).

[25] A. Dimovski, Recherches zoocénologiques dans les steppes de Macédoine, Annuaire de la Faculté des Sciences de l'Université de Skopje, 23 (1971), pp. 25-43, (In Macedonian, French summary),

[26] D. P. Chobanov, Results of the orthopterological investigations from Ogražden and Kozjak Mts. Republic of Macedonia, Bulletin of the Biology's Students Research Society, Skopje, 2 (2002), pp. 111117.

[27] B, Micevski, D. Chobanov, D. Pop-Stojanov, [The Fauna of Orthoptera of the National Park Pelister], BSPSM 4, Skopje, (2003), 99 p. (In Macedonian).

[28] D. P. Chobanov, K. G. Heller, Revision of the Poecilimon ornatus group (Orthoptera: Phaneropteridae) with focus on Bulgaria and Macedonia, Eur. J. of Entomology, 107 (2010), pp. 647-672.

[29] I. Karaman, N. Hammouti, D. Pavićević, A. Kiefer, M. Horvatović, A. Seitz, The genus Troglophilus Krauss, 1879 (Orthoptera: Rhaphidophoridae) in the west Balkans, Zool. J. Lin. Soc., 163 (2011), pp. 1035-1063.

[30] D. P. Chobanov, M. Lemonnier-Darcemont, C. Darcemont, G. Puskás, K.-G. Heller, Tettigonia balcanica, a new species from the Balkan Peninsula (Orthoptera, Tettigoniidae), Entomologia, 2 209, (2014), pp. 95-106.

[31] M. Lemonnier-Darcemont, A short note on Orthoptera from the Republic of Macedonia (F.Y.R.O.M): new species for the country and new data, Articulata, 26 (2010), pp. 1-4.

[32] D. P. Chobanov, B. Grzywacz, I. Iorgu, B. Ciplak, M. Ilieva, E. Warchałowska-Śliwa, Review of the Balkan Isophya (Orthoptera: Phaneropteridae) with particular emphasis on the Isophya modesta group and remarks on the systematics of the genus based on morphological and acoustic data, Zootaxa 3658 (2013), pp. 1-81.

[33] M. Lemonnier-Darcemont, D. Chobanov, V. Krpac, Red list of Orthoptera of the Republic of Macedonia, Revue d'écologie (La terre et la vie), 69 (2014), pp. 151-158.

[34] G. [Peshev, G.] Pesev, Composition et repartition oecologique des Orthoptères de la montagne Belasitsa, Bull. Zool. Inst. Mus., 12 (1962), pp. 59-107 (in Bulgarian, French summary).

[35] D. P. Chobanov, Analysis and evaluation of the faunistic diversity of the orthopterous insects (Orthoptera) in Bulgaria, $\mathrm{PhD}$ thesis, Institute of Zoolo- 
gy, Bulgarian Academy of Sciences, Sofia, (2009), 565 pp. (in Bulgarian, English summary).

[36] Lj. Melovski, B. Markovski, S. Hristovski, D. Jovanovska, V. Anastasovski, S. Klincharov, M. Velevski, N. Velkovski, A. Trendafilov, V. Matevski, M. Kostadinovski, M. Karadelev, Z. Levkov, D. Kolchakovski, Regional division of the
Republic of Macedonia for the needs of biological databases, Macedonian Journal of Ecology and Environment, 15, (2013), pp. 81-111.

[37] G. Filipovski, R. Rizovski, P. Ristevski, The characteristic of the climate-vegetation-soil zones (regions) in the Republic of Macedonia, Macedonian Academy of Sciences and Arts, Skopje, 1996.

\title{
ПРИДОНЕС КОН ПРОУЧУВАЊЕТО НА ОРТОПТЕРСКАТА ФАУНА \\ НА ПЛАНИНАТА БЕЛАСИЦА, ЈУГОИСТОЧНА МАКЕДОНИЈА
}

\author{
Александра Цветковска-Ѓ⿱орѓ́евска ${ }^{1 *}$, Драган П. Чобанов ${ }^{2}$, Дана Прелиќ ${ }^{1}$, \\ Славчо Христовски ${ }^{1}$, Валентина Славевска-Стаменкович ${ }^{1}$, Милица Ристовска ${ }^{1}$ \\ ${ }^{1}$ Институт за биологија, Природно-математички факултет, Архимедова 5, \\ 1000 Скопје, Р. Македонија \\ ${ }^{2}$ Іинститут за биодиверзитет и екосистемски истражувања, Бугарска академија на науките, \\ Цар Ослободител 1, 1000 Софија, Бугарија
}

Трудот опфаќа фаунистички податоци за ортоптерската фауна која ја населува планината Беласица. Истражувањето е спроведено во локалитети долж височински градиент на северната страна од планината, во периодот април-ноември 2010 година. Регистрирано е присуство на 16 видови правокрилци, кои припаѓаат на 6 фамилии, 9 потфамилии и 16 родови.

Клучни зборови: Orthoptera; Беласица; југоисточна Македонија 
